\title{
Cuminum cyminum - A Popular Spice: An Updated Review
}

\author{
Rudra Pratap Singh, Gangadharappa H.V.*, Mruthunjaya K
}

\section{Rudra Pratap Singh, Gangadharappa H.V.*, Mruthunjaya K}

Department of Pharmaceutics, JSS College of Pharmacy, JSS University, Sri Shivarathreeshwara Nagar, Mysuru, Karnataka, INDIA.

\section{Correspondence}

Gangadharappa H.V,

Department of Pharmaceutics, JSS College of Pharmacy, JSS University, SS Nagar, Mysuru 570015, Karnataka, INDIA.

Phone no: + 91-9986042737

E-mail: hvgangadharappa@jssuni.edu.in

History

- Submission Date: 27-02-17;

- Review completed: 20-03-17.

- Accepted Date: 22-03-17

DOI : 10.5530/pj.2017.3.51

Article Available online http://www.phcogj.com/v9/i3

\section{Copyright}

(C) 2017 Phcog.Net. This is an openaccess article distributed under the terms of the Creative Commons Attribution 4.0 International license.

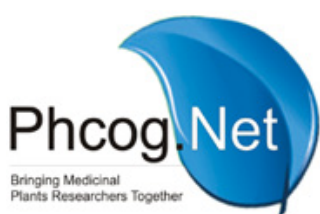

\begin{abstract}
Spices are bio-nutrient supplements that enhance the taste, flavor and aroma of food and also treat several diseases. Cumin (Cuminum cyminum) is one such most popular spice that is used as a culinary spice for their special aromatic effect. Cumin is a traditional and much used spice from Middle Ages because it was an icon of love and fidelity. Cumin is available in different appearances such as anise, fennel and black cumin and the difference between them is their characteristics. The proximate analysis of the cumin seeds reveals that they contain fixed oil, volatile oils, acids, essential oils, protein and other elements. In cumin, contains an important component such as pinene, cymene, terpinene, cuminaldehyde, oleoresin, thymol and others that have shown their uses according to the disease. Cumin has proved several benefits with the help of availability of nutrients. It is an important element of iron for energy, immunity systems, lactation and skin diseases. Cumin also shown various pharmacological effects but has some side effects. So, volatile plants generally come out as a complex mixture of less molecular weight lipophilic compounds that derived from different biosynthetic pathways and also contribute to a variety of physiological functions.

Key words: Spice, Cumin, Cuminaldehyde, Cymene, Thymol.
\end{abstract}

\section{INTRODUCTION}

Spices are an important bionutrients for both food ingredients and nutritional supplements. From ancient times, spices have been used as food additives to enhance the taste and be flavor of food. Apart from these uses, spices also have numerous medicinal properties and used to treat several disorders that form an important part of the Ayurvedic Pharmacopoeia (Indian System of Medicine). Spices have increasingly larger role to play in Indian recipes as the bactericidal, bacteriostatic, fungistatic, antifertility, antihelminthic and other medicinal properties and also believed to aid digestion. In the traditional Indian system of medicine, more than a few spices and herbs have hold and possess several medicinal properties such as antithrombotic, anti-atherosclerotic, hypolipidemic, antiinflammatory, anti-aggregatory, eicosanoid inhibitor. ${ }^{1}$

Cumin is popular as culinary spice and used in folklore therapy because the presence of aromatic substances in the herb. Cumin comes under the category of traditional spice from middle ages. It was too much popular, because of its peppery flavor. During the middle ages in Europe, cumin became as an icon of love and fidelity and also some people wants to carry cumin in their pockets to give in wedding ceremonies. Cumin is a small hairy, brownish in color, boat shaped seed plant that have a spicy sweet aroma property and powerful slightly bitter and pungent flavor. ${ }^{2}$

The scientific name of Cuminum cyminum L. (cumin) referred to as Cuminum odorum Salisb, Cuminia cyminum J.F. Gmel, Cuminum hispanicum Bunge, Ligusticum cuminum (L.) Crantz and belonging to the Apiaceae family. ${ }^{3}$ The Apiaceae family is a collection of typically aromatic plants having hollow stems and the wellknown members of this family are anise, asafoetida, caraway, carrot, celery, coriander, cumin, dill, fennel, parsley, parsnip, and sea holly.

In traditional medicines, cumin was a major component of curry and chili powder that was used to flavor a variety of commercial food products. Cumin has also been crushed and mixed with foods such as fish and meat, and the seeds sprinkled on bread and cakes. The oil, derived by steam distillation, is used to flavor alcoholic beverages, desserts, and condiments. It is also used as a fragrant component of creams, lotions, and perfumes. Cumin has been used as anti-inflammatory, diuretic, carminative, and antispasmodic, treatment of toothaches and epilepsy and also as an aid for treating dyspepsia, jaundice, diarrhea, flatulence, and indigestion. Cumin powder has been used as a poultice and suppository and has been smoked in a pipe and taken orally. The cumin plant and its essential part is one of the most common aromatics in the Mediterranean kitchen. It is one of the popular spices regularly used as a flavoring agent. Cumin is an annual cultivated herb, with an erect, round, slender, branched stem, about a foot high. ${ }^{2}$

The available and useful parts of cumin plants are described below:

Leaves: The leaves of cumin are multi-fid, with long filiform segments.

Flowers: The flowers, small, white, or pink are overtopped by the bracts, which, after flowering, are reflexes. The umbels, both partial and general, 
consist of about 5 rays, with the involucres consisting of 2 or 3 filiform, 1 sided bracts.

Fruits: The fruits of cumin are ovate or fusiform, of a light brown or grayish color. The fruit resembles caraway, but is larger and about 2 lines in length, much longer than the pedicels, nearly tapering, but little contracted at the sides, fusiform, crowned by the short teeth of the calyx, densely covered with short rough hair upon the channels, and less densely upon the ridges, which are paler, filiform, and a little raised; The seeds or half fruits, 2 in number, are oblong; Plano convex, with the plane surfaces together (L.).The odor and taste of cumin fruit is similar to caraway, but it's so warmer and not so agreeable.

Seeds: The cumin seed is yellow to brownish-gray in color and is elongated in shape with nine protuberances that possesses numerous medicinal properties. The seeds of cumin are carminative, aromatic, stomachic, stimulant, astringent and cooling and synergistic ${ }^{4}$ in effect. Cumin seed oil is used as multifunctional luminescent paints or in topical clothing ointment.

Cumin is an aromatic herb and an astringent that benefits the digestive apparatus. It has been used in the treatment of mild digestive disorders as a carminative and eupeptic, as and astringent in bronco pulmonary disorders and as a cough remedy, as well as an analgesic. ${ }^{5}$

The essential oil of cumin seeds has shown a significant antibacterial activity against K. pneumoniae in vitro. ${ }^{6}$

\section{OTHER FRUITS OF APIACEAE FAMILY}

There are many fruits from the same family that have the similar appearance and properties. There is Persian cumin or meridian fennel for caraway, black cumin for nigella, and sweet cumin for aniseed or fennel, as a general rule interprets jeera or zeera (jira, zira) as cumin and kalonji as nigella. The similarity in odor or appearance (Figure 1), biological name and uses of the members of Apiaceae family is shown in Table. 1.

\section{Caraway}

Caraway (Carum carvi L.) Figure 2, is defined as the dried ripe fruit of the biennial, usually white-flowered, aromatic herb. It is also known as
Persian cumin or meridian fennel, and is one of the ancient cultivated plants of Asia, Africa and Europe. ${ }^{7}$ The plant resembles a carrot plant with feathery leaves and threadlike divisions, growing on $20-30 \mathrm{~cm}$ (7.9-11.8 in) stems and the flower stem is tall, slender, branched, and hollow-stemmed, $30-80 \mathrm{~cm}$ (16-24 in) in height. A large number of phytoconstituents including different flavonoids, iso-flavonoids, flavonoid glycosides, monoterpenoids such as carvone and its derivatives, glucosides, lignins, and alkaloids, as well as polyacetylenic compounds, ${ }^{8-12}$ different vitamins, amino acids, proteins, and minerals, also starch, sugars and other carbohydrates, tannins, phytic acid, and dietary fibers ${ }^{13}$ are present in caraway. Carvone and limonene are usually reported as the main phytochemicals present in caraway seeds. The other important compounds extracted usually from hydro/steam distillation include: carvacrol, a-pinene, g-terpinene, linalool, carvenone, and p-cymene. ${ }^{14-16}$ The fruits of caraway are used extensively as a mild spice and flavoring for culinary purposes in many cuisines. The dried, brown fruits are hard, crescent-shaped achenes, around $2 \mathrm{~mm}$ long with five pale ridges. The fruits are similar to cumin which has a pleasant odor, and an aromatic flavor and sharp taste. In Middle East countries they are distinguished by their color; caraway is known as black zeereh and cumin seeds known as green zeereh. ${ }^{17}$ Caraway seeds are also widely used in various systems of traditional medicine and the aromatic constituents have been studied for their health benefits.

\section{Treatment and Uses of caraway}

Caraway is well known as a traditional medicinal plant with a long history of healing. Cumin has reported to have potent medicinal properties such as antispasmodic, antiseptic, antiparasitic, lactigenic, hypolipidemic, antiflatulance, aromatic, carminative, digestive and stimulant. It is also recommended for the treatment of toothache, diarrhea, and epilepsy. ${ }^{17}$

\section{Black cumin}

Black cumin (Bunium persicum) Figure 3, is also popular as wild or shahi jeera in the Persian and Indian subcontinent and it is related appearance of regular cumin. Its seeds feature long, slender, curved, darkbrown pods with distinctive earthy flavor. Nigella sativa Linn. (N. sativa), it's also

\section{Table 1: Appearance and properties of the Apiaceae family members}

\begin{tabular}{|c|c|c|c|c|}
\hline Biological name & Common name & Other names & Active constituents & Uses \\
\hline Carum carvi & $\begin{array}{l}\text { Caraway seed, caraway fruit, } \\
\text { persian cumin, meridian fennel }\end{array}$ & $\begin{array}{c}\text { Jiraa, zeera siyaah, kamoon, } \\
\text { kamoon-roomi }\end{array}$ & $\begin{array}{l}\text { Carvone, limonene carvacrol, } \\
\text { a-pinene, g-terpinene, linalool, } \\
\text { carvenone, and p-cymene }\end{array}$ & $\begin{array}{l}\text { Antispasmodic, antiseptic, } \\
\text { antiparasitic, lactigenic, } \\
\text { hypolipidemic, aromatic, } \\
\text { carminative, digestive, stomach- } \\
\text { calming and stimulant }\end{array}$ \\
\hline Bunium persicum & $\begin{array}{c}\text { Black cumin, black seed, } \\
\text { Nigella sativa }\end{array}$ & $\begin{array}{c}\text { Jirak, jiraa siyah, } \\
\text { kamoonarmani, } \\
\text { shahi jeera, kaala jeera }\end{array}$ & Nigellone and thymoquinone & $\begin{array}{l}\text { Hypotensive, uricosuric, choleretic, } \\
\text { antifertility, antidiabetic, anti- } \\
\text { histaminic, anti-oxidant, anti- } \\
\text { inflammatory, anti-microbial, } \\
\text { anti-tumor }\end{array}$ \\
\hline Cuminum cyminum & Cumin, Jeera & Safed jeeraa, kamun & $\begin{array}{l}\text { b-pinene, } \mathrm{p} \text {-cymene, } \\
\text { g-terpinene, and cuminaldehyde }\end{array}$ & $\begin{array}{c}\text { Carminative, eupeptic, astringent, } \\
\text { antibacterial, cough remedy and } \\
\text { analgesic }\end{array}$ \\
\hline Pimpinella anisum & Anise, aniseed, sweet cumin & $\begin{array}{c}\text { Saumph, aneesun, anysum, } \\
\text { anise seed, anisi, anisi fructus, } \\
\text { anisi vulgaris }\end{array}$ & $\begin{array}{c}\text { trans-anetole, estragole } \\
\gamma \text {-hymachalen, para- } \\
\text { anisaldehyde and } \\
\text { methyl cavicol }\end{array}$ & $\begin{array}{l}\text { Antiseptic, antifungal, } \\
\text { antispasmodic, tonic, appetizer, } \\
\text { stimulator and carminative, } \\
\text { perfumery agent, dentifrice and } \\
\text { mouthwash. }\end{array}$ \\
\hline Foeniculum vulgare & Sweet cumin, sweet fennel & $\begin{array}{l}\text { Perum jeerakam, fenicol, } \\
\text { fenikel, fenkel, fenkhel, } \\
\text { fenkoli, fennel oil, saunf, } \\
\text { shamaar, sombu, sonf, sopu, } \\
\text { spice of the angels }\end{array}$ & $\begin{array}{l}\text { Anethole, } \alpha \text {-pinene, } \\
\beta \text {-myrcene, } \beta \text {-pinene, fenchone, } \\
\text { camphene, estragole, fenchone, } \\
\text { limonene, } p \text {-cymen, and safrole }\end{array}$ & $\begin{array}{c}\text { Carminative, cold, cough and cattle } \\
\text { condiment }\end{array}$ \\
\hline
\end{tabular}


known as black seed or black cumin, is an herbaceous plant, generally grows in the Middle East, Central Europe and Western Asia, used as food seasoning in the Mediterranean region. It is commonly used in indigenous system of medicine and in Arab traditional medicine for treatment of various disorders such as arthritis, lung diseases and hypercholesterolemia for over 2000 years. ${ }^{18-20}$ Other pharmacological properties of it includes hypotensive, anti-nociceptive, uricosuric, choleretic, antifertility, antidiabetic, anti-histaminic, anti-oxidant, anti-inflammatory, anti-microbial, anti-tumor and immunomodulatory effects. ${ }^{21}$ The rich component of its nigellone and thymoquinone, about $27 \%-57 \%$ and has numerous medicinal values. ${ }^{22-24}$

The fruits of black cumin are used in bread, rice, cheese and yogurt processing for its carminative, anti flatulent, antispasmodic and antimicrobial effects, besides the pleasant smelling characteristic. Fruits essential oil is usually used for losing weight and as lactogogue as well. The essential volatile oil of seeds of black cumin, contains more than sixty constituents that responsible for the pleasant fresh, clean, spicy (typical cumin-like) odour of a high quality product. Cumin aldehyde (36\%), b-pinene (19.3\%), p-cymene (18.4\%) and c-terpinene $(15.3 \%)$ are the principal compounds of cumin seed oils.

\section{Treatment and Uses of black cumin}

Black cumin is used in traditional medicine to treat headache, coughs, abdominal pain, diarrhea, asthma and rheumatism. The aqueous and oil extracts of the black cumin seeds have been shown to possess antioxidant, anti-inflammatory, anticancer, analgesic, antimicrobial activities and applications has in sanitary, cosmetic, agricultural and food industries. Black cumin seeds have been also used by patients to suppress coughs disintegrate renal calculi, retard the carcinogenic process, ${ }^{25-26}$ treat abdominal pain, diarrhea, flatulence and polio, ${ }^{27}$ exert choleretic and uricosuric activities, carminative, stimulatory and diaphoretic properties, anti-inflammatory ${ }^{28,29}$ and antioxidant effects. ${ }^{30,31}$ It is also used in the treatment of bronchial asthma and eczema. ${ }^{32}$

Besides, the essential oil of black cumin was shown to have antihelminthic, ${ }^{33}$ antinematodal, ${ }^{34}$ antischistosomal, ${ }^{35}$ antimicrobial ${ }^{36-38}$ and antiviral ${ }^{39}$ and also headache, flatulence, blood homeostasis abnormalities, rheumatism and related inflammatory diseases effects. ${ }^{32}$

\section{Anise}

Anise (Pimpinella anisum) Figure 4 is a dainty, white flowered herbaceous annual plant growing to $1.6 \mathrm{ft}-3 \mathrm{ft}$ or more tall. The leaves at the base of the plant are simple, $1-5 \mathrm{~cm}$ long and shallowly lobed, while leaves

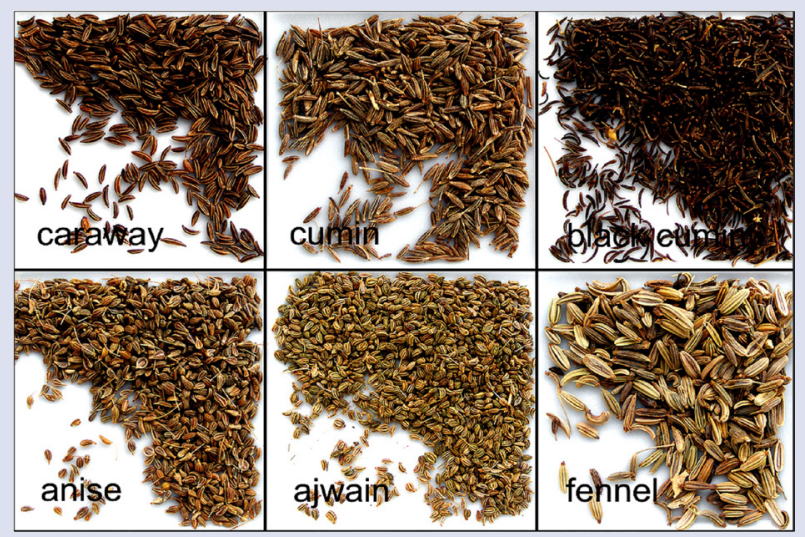

Figure 1: Similar appearance of family members of Apiaceae higher on the stems are feathery pinnate, divided into numerous small leaflets. The flowers are white, approximately $3 \mathrm{~mm}$ in diameter, produced in dense umbels. The fruit is an oblong dry schizocarp, aromatic and provided with 5 rows and 3-6 mm long in diachenium. ${ }^{8,40}$ Anise is very helpful in cold and cough, anemia, asthma, morning sickness, gas pain, sore throat and in bad breath. It is also used as antiseptic, antispasmodic, tonic, appetizer, stimulator and carminative. Essential oil of anise is used as perfumery agent in tooth paste and as a flavor for foods. The powdered form of anise is useful for dentifrice and mouthwash. ${ }^{41}$

\section{Fennel}

Fennel (Foeniculum vulgare) Figure 5 is a thick, perennial root-stock herb. It is erect and cylindrical, bright green, and grows to heights of up to 4 to 5 feet, with hollow branched stems. The leaves grow up to $40 \mathrm{~cm}$ long with the ultimate and finest segments filiform (threadlike), about $0.5 \mathrm{~mm}$ wide. The bright golden flowers are produced in terminal umbels 5-15 cm wide, each umbel section having 20-50 tiny yellow flowers on short pedicels. The fruit is a dry seed from $4-10 \mathrm{~mm}$ long, half as wide or less and grooved. ${ }^{8}$ Because of aromatic and carminative properties, Fennel is used as a food flavor ingredient. It is used for cold and cough in home remedy treatment and also largely used for cattle condiment. ${ }^{42}$

\section{CULTIVATION AND HARVESTING}

Cumin is a small flowering herbaceous plant belonging in the Apiaceae, family, in the genus; Cuminum. The cumin plant flourishes well in sandy, fertile soil, assisted with hot summer weather conditions. It bears small, gray yellow, oblong shaped seeds with vertical ridges on their outer surface. It is cultivated in Arabia, India, China and in the countries bordering the Mediterranean Sea. ${ }^{43}$ Cultivation of cumin requires a long, hot summer of 3-4 months, with day time temperatures around $30^{\circ} \mathrm{C}$; it is drought tolerant, and is mostly grown in mediterranean climates. It is grown from seed, sown in spring, and needs fertile, well-drained soil. ${ }^{44}$ Cumin seeds are used as a spice for their distinctive aroma, popular in Indian, Pakistan, North African, Middle Eastern, Sri Lankan, Cuban, Northern Mexican cuisines, and the Western Chinese cuisines of Sichuan and Xinjiang. ${ }^{45}$ The cumin plant grows to $30-50 \mathrm{~cm}$ tall and is harvested by hand. ${ }^{46}$

\section{CHEMISTRY AND COMPOSITION}

The cumin seeds contain aldehyde (60\%) fats, amino acids, flavonoids and glycosides $(22 \%)$, volatile oil (2-5\%) and the yellow colored fresh oil contains cuminaldehyde as its chief component. ${ }^{47,48}$ The major

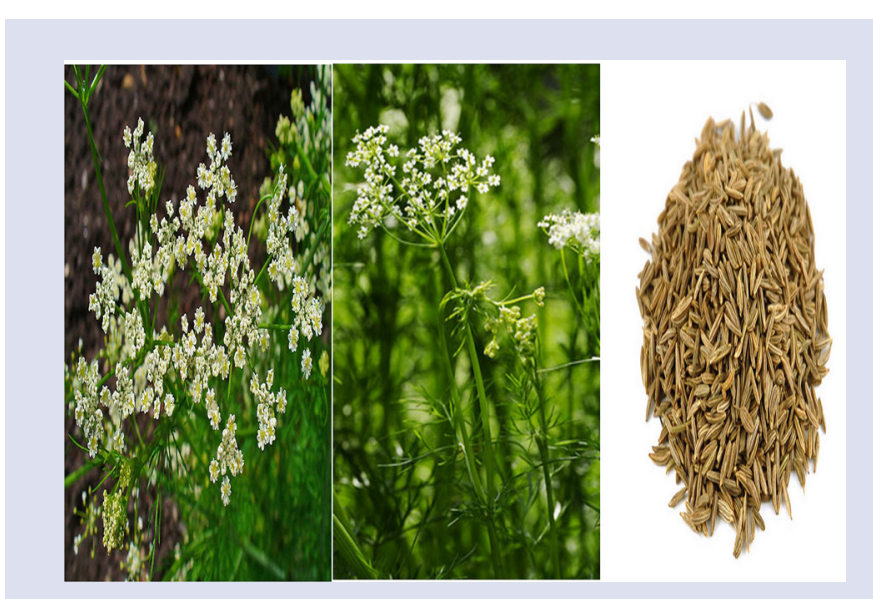

Figure 2: Caraway (Carum carvi L.) 


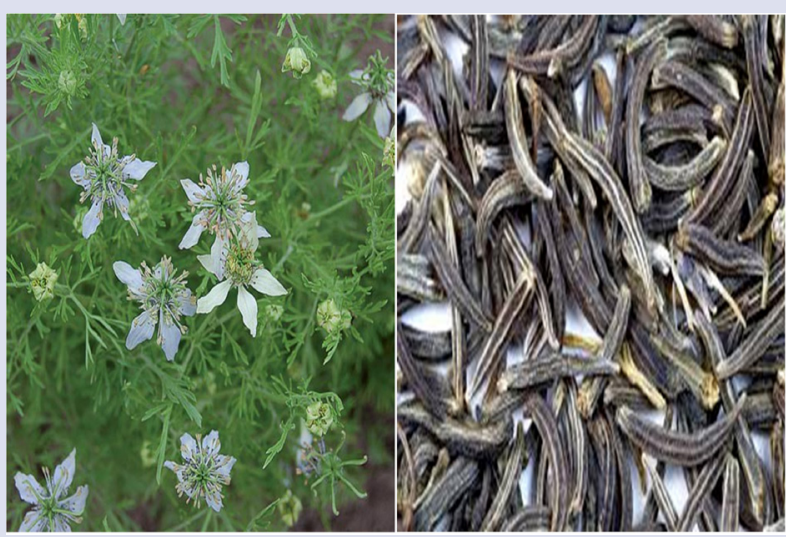

Figure 3: Black cumin (Bunium persicum)

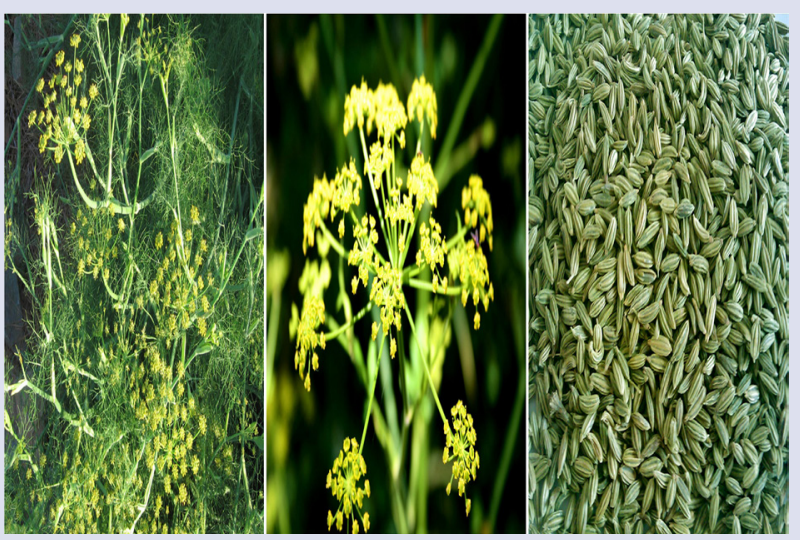

Figure 5: Fennel (Foeniculum vulgare)

compounds occurring in cumin are cuminaldehyde, limonene, $\alpha$ - and $\beta$-pinene, 1, 8-cineole, $o$-and $p$-cymene, $\alpha$ - and $\gamma$-terpinene, safranal and linalool has shown in Figure 6.

The cumin fruit contains resin, fatty matter, gum, lignin, protein bodies and salts, largely composed of malates, extractive, and volatile oil. The proximate composition of the seeds indicates that they contain fixed oil (approximately 10\%), protein, cellulose, sugar, mineral elements and volatile oil. ${ }^{49}$ Cumin seeds contain volatile oil (1-5\%) that imparts the characteristic aroma to the seeds. After the separation, a plenty number of phenolic compounds are identified in cumin fruits that includes phenolic acids, flavonoids, phenolic diterpenes, that are closely associated with their antioxidant activity and play an important role in inhibiting lipid peroxidation and various types of oxidizing enzymes. ${ }^{50}$

The identified essential oils in cumin are octanol, limonene, thymol, anisyl alcohol, cuminaldehyde, anethole, vanillin and also benzoic acid. The presenting organic acids in cumin are aspartic, citric, malic, tartaric, propionic, ascorbic, oxalic, maleic and fumaric acids and phenols are salicylic acid, gallic acid, cinnamic acid, hydroquinone, resorcinol, p-hydroxybenzoic acid, rutin, coumarine and quercetin. The cumin oil is used as a fragrance component in cosmetics (maximum use level $0.4 \%$ in perfumes.

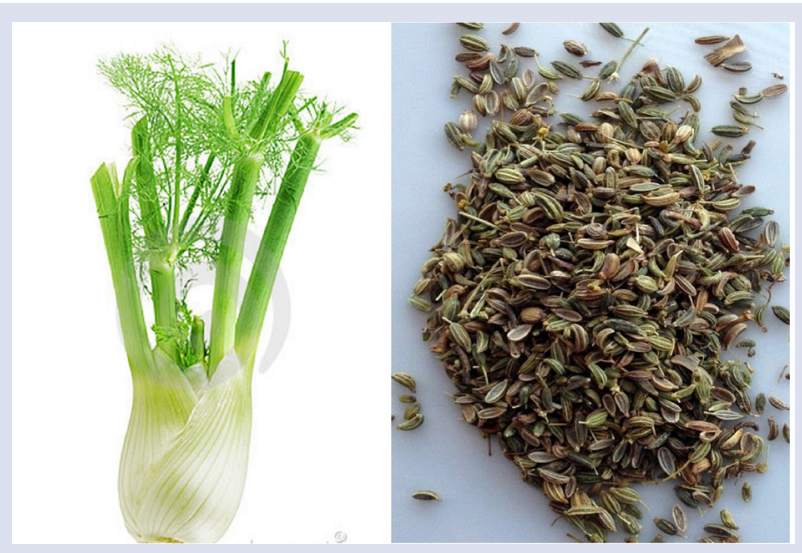

Figure 4: Anise (Pimpinella anisum)

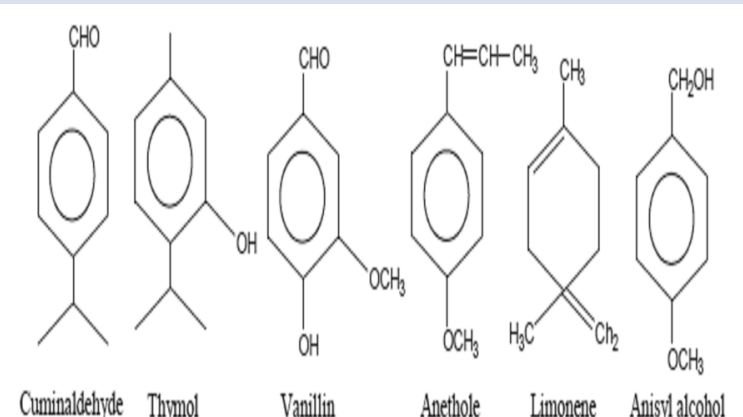

Figure 6: Structure of active compounds of cumin

\section{Components of Cumin}

The essential oil of cumin contains high levels of phenolic compounds, mainly cumin aldehyde, and para-cymene. The antioxidant activities of b-pinene, p-cymene, g-terpinene, cuminaldehyde and cumin oils (cumin oleoresin/COR, cumin essential oil/CEO, distillation residue/DR and distillate condensed from cold trap/ CT). The two standard active constituent of cumin such as cuminaldehyde and para-cymene have used to protect liver against oxidative stress and disease by increases the enzyme activities and malondialdehyde.

Cuminaldehyde (4 - isopropyl benzaldehyde) is an aromatic monoterpenoid volatile compound and a constituent of the essential oils of eucalyptus, myrrh, Cuminum cyminum, ${ }^{3}$ Carum carvi, ${ }^{8,47}$ Cinnamomum cassia ${ }^{51}$ and others. ${ }^{8,17}$ Cuminaldehyde has molecular formula $\mathrm{C}_{10} \mathrm{H}_{12} \mathrm{O}$ that is a substitute of benzaldehyde with an isopropyl group in the $4^{\text {th }}$ position. It has pleasant aroma and has been used commercially in perfumes and cosmetics. The molecular weight of this colorless compound is $148.2 \mathrm{~g} \mathrm{~mol}^{-1}$. $^{3}$

Cuminaldehyde can be synthesized by two methods:

1. By the reduction of 4-isopropylbenzoyl chloride

2. By the formylation of cumene. 
Cuminaldehyde is used commercially in perfumes and other cosmetics. It is also used to inhibit the fibrillation of alpha-synuclein $(\alpha-\mathrm{SN}),{ }^{52}$ Parkinson's disease and viral infections.

Cuminaldehyde has shown different effects such as anti-platelet, ${ }^{53}$ antibacterial, ${ }^{3}$ antifungal,,$^{54}$ anti-diabetic, ${ }^{55}$ anti- Parkinson's ${ }^{56}$ and it also activates salivary glands in mouth and facilitates the primary digestion of the food and produce carminative effects. Cuminaldehyde has been under study to verify its effectiveness as an antitumor agent and has shown good results on cultured murine but not on cultured human cells. Paracymene is a cyclic organic compound with the molecular formula $\mathrm{C}_{10} \mathrm{H}_{14}$. This compound belongs to alkyl benzene group and is related to monoterpene. Its structure contains a benzene ring with two methyl isopropyl groups. Para-cymene is insoluble in water but soluble in ethanol. The molecular weight of this colorless compound is $134.21 \mathrm{~g} \mathrm{~mol}^{-1}$. $^{57}$

Another important component of cumin is thymol that has the molecular formula $\mathrm{C}_{10} \mathrm{H}_{14} \mathrm{O}$ and molecular weight $150.22 \mathrm{~g} \mathrm{~mol}^{-1}$. The secretion of acids, bile and enzymes by thymol is same as to the gland and play an important role in as stimulator.

\section{NUTRITIONAL PROFILE OF CUMIN}

Cumin seeds contain numerous phytochemicals that are known to have antioxidant, carminative and antiflatulent properties. The seeds are an excellent source of dietary fiber. Its seeds contain certain health benefits essential oils such as cuminaldehyde (4-isopropylbenzaldehyde), pyrazines, 2-methoxy-3-secbutylpyrazine, 2-ethoxy-3-iso propylpyrazine, and 2-methoxy-3-methylpyrazine. The active principles in the cumin may improve gut motility and help in digestion. ${ }^{58,59}$ As per USFDA, the nutritional profile of cumin is given below in Table 2 .

\section{HEALTH BENEFITS OF CUMIN}

Cumin has the following benefits that are described below: ${ }^{58,59}$

\section{Common benefits}

Cumin used in healing the cuts and bleeding and as an antiseptic. Cumin is a stimulant as well as a great herb for digestive disorders, stimulate the secretion of enzymes from the pancreas which can help absorb nutrients into the system, boost the power of the liver's ability to detoxify the human body, anticarcinogenic properties, reduce the risk of stomach and liver tumors and also boost immune system. Cumin also has the useful benefit effects such as increasing urine flow, settling upset stomach, eliminating gas, and improving the symptoms of carpal tunnel syndrome.

\section{Iron for Anemia and Immune Function}

Cumin is very rich in iron (above $66 \mathrm{mg}$. in each 100 grams) which is more than 5 times the daily requirement of iron for an adult. Cumin seeds are a very good source of iron and minerals that plays many vital roles in the body. Iron is an integral component of hemoglobin, which transports oxygen from the lungs to all body cells, and is also part of key enzyme systems for energy production and metabolism. So, cumin can be a nutritious additive to daily diet for anemic people. Additionally, iron is instrumental in keeping your immune system healthy.

\section{Lactation}

It is rich in iron and thus very good for lactating mothers as well as women who are undergoing menses or who are pregnant, since they are more in need of iron than others. Iron is particularly important for menstruating women, who lose iron during menses. Growing children and adolescents have increased needs for iron, as do women who are pregnant or lactating. Moreover, cumin is said to help ease and increase secretion of milk in lactating women due to presence of thymol, which tends to increase secretions from glands, including milk which is a secre- tion from mammary glands. It is more beneficial if taken with honey. Cumin has remarkable amount of calcium (above $900 \mathrm{mg}$ per $100 \mathrm{~g}$ ) which accounts to over $90 \%$ of our daily requirement of calcium. This calcium is an important constituent of milk and hence cumin is very good for lactating mothers.

\section{Skin Disorders}

Almost all of us know that vitamin E is good for skin. It keeps the skin young and glowing. This vitamin is also present in abundance in cumin. The essential oils present in this have disinfectant and anti fungal properties. This prevents any microbial and fungal infection from affecting the skin.

\section{Boils/Removal of toxins}

Boils are just outlets for removal of toxic substances and foreign matters such as microbes etc. from the body. So, they are rather symptoms which show that a lot of toxic substances have accumulated in the body. Those who regularly use cumin in food have been seen keeping free from boils, rashes, pimples etc. Components such as cuminaldehyde, thymol, phosphorus etc. are good detoxicants which help in the regular removal of toxins from body, through excretory system of course, and not through boils.

\section{Other benefits}

Cumin is also beneficial in treating renal coli, weak memory or lack of concentration, insect bites and sting etc.

\section{USES OF CUMIN}

\section{General uses}

Cumin seeds are used in cooking to flavor food also as a spice. The components of cumin may have antioxidant, anticancer, antibacterial, and larvicidal effects. It is also used to lower blood sugar, reduce seizures, strengthen bones, and treat the eye.

\section{Traditional uses}

Traditional uses of cumin include reducing inflammation, increasing urination, preventing gas and suppressing muscle spasms. It is also used as an aid for indigestion, jaundice, diarrhea, and flatulence, poultice and suppository, and has been taken orally. Cumin is a major component of curry and chili powders that used to flavor a variety of food products. It is used to flavor alcoholic beverages, desserts, and condiments. Cumin also used as a fragrant component of creams, lotions, and perfumes. In different traditional systems, cumin is considered as stimulant, carminative and astringent, abortive, galactagogue, antiseptic, antihypertensive herb, bitter tonic, and purgative and its therapeutic effects have been described on gastrointestinal, gynecological and respiratory disorders, and also for the treatment of toothache, diarrhea and epilepsy. ${ }^{59-62}$

\section{Pharmacological Uses}

Cumin and its active constituents used as a antibacterial, antifungal, anti-inflammatory, antioxidant, astringent, atherosclerosis (hardening of the arteries), blood thinner, bone loss, cancer, cardiovascular disease, carpal tunnel syndrome, cataracts (eye disease), cavities, dental plaque, diabetes, digestion, diuretic (improves urine flow), ear infections, food uses (flavoring and preservative), gas, gastrointestinal disorders, general health maintenance, general stimulant, high cholesterol, immune modulation (affects the immune system), insect repellant, insecticidal, low blood sugar, menstrual flow stimulant, promoting flow of breast milk, relaxation, seizures/epilepsy, ulcers, weight loss. The pharmacological activities or uses of cumin are described below: 
Table 2: Nutritional Profile of Cumin

\begin{tabular}{|c|c|c|c|c|}
\hline Types of Nutrient & Examples of nutrient & Applications & Nutrient Value & Percentage of RDA \\
\hline \multirow[t]{6}{*}{ Minerals } & Iron & Required for red blood cell formation & $66.36 \mathrm{mg}$ & $829 \%$ \\
\hline & Copper & $\begin{array}{l}\text { Required in the production of red } \\
\text { blood cells }\end{array}$ & $0.867 \mathrm{mg}$ & $96 \%$ \\
\hline & Calcium & --- & $931 \mathrm{mg}$ & $93 \%$ \\
\hline & Manganese & $\begin{array}{l}\text { Used by the body as a cofactor for } \\
\text { the powerful antioxidant enzyme, } \\
\text { superoxide dismutase }\end{array}$ & $3.3 \mathrm{mg}$ & $145 \%$ \\
\hline & Selenium & --- & --- & --- \\
\hline & Zinc & $\begin{array}{l}\text { Zinc is a cofactor in many enzymes } \\
\text { that regulate growth and development, } \\
\text { digestion and nucleic acid synthesis }\end{array}$ & $4.8 \mathrm{mg}$ & $43.5 \%$ \\
\hline \multirow[t]{2}{*}{ Electrolytes } & Potassium & $\begin{array}{l}\text { It's an important component of cell } \\
\text { and body fluids that helps controlling } \\
\text { heart rate and blood pressure }\end{array}$ & $68 \mathrm{mg}$ & $11 \%$ \\
\hline & Sodium & --- & $1788 \mathrm{mg}$ & $38 \%$ \\
\hline \multirow[t]{9}{*}{ Vitamins } & Vitamin (B complex) & Anti-oxidants & $0.628 \mathrm{mg}$ & $52 \%$ \\
\hline & Thiamin Riboflavin & & $0.32 \mathrm{mg}$ & $24.5 \%$ \\
\hline & Niacin & & $4.58 \mathrm{mg}$ & $28.5 \%$ \\
\hline & Pyridoxine & & $0.435 \mathrm{mg}$ & $33 \%$ \\
\hline & Folic acid & & $10 \mu \mathrm{g}$ & $2.5 \%$ \\
\hline & Vitamin E & Anti-oxidants & $3.3 \mathrm{mg}$ & $22 \%$ \\
\hline & Vitamin A & & $7.7 \mathrm{mg}$ & $13 \%$ \\
\hline & Vitamin C & & $1270 \mathrm{IU}$ & $42 \%$ \\
\hline & Vitamin K & & $5.4 \mu \mathrm{g}$ & $4.5 \%$ \\
\hline \multirow[t]{3}{*}{ Phyto-nutrient } & Carotenes & Anti-oxidants & $762 \mu \mathrm{g}$ & - \\
\hline & Zeaxanthin & & $0 \mu \mathrm{g}$ & - \\
\hline & Lutein & & $448 \mu \mathrm{g}$ & - \\
\hline \multirow[t]{6}{*}{ Others } & Energy & --- & $375 \mathrm{Kcal}$ & $19 \%$ \\
\hline & Carbohydrate Protein & & $44.24 \mathrm{~g}$ & $24 \%$ \\
\hline & Fat & & $17.8 \mathrm{~g}$ & $32 \%$ \\
\hline & Fibers & & $22.27 \mathrm{~g}$ & $74 \%$ \\
\hline & Cholesterol & & $10.5 \mathrm{~g}$ & $26 \%$ \\
\hline & & & $0 \mathrm{mg}$ & $0 \%$ \\
\hline
\end{tabular}

\section{Antioxidant}

The cumin oils have high antioxidant activity due to presence of monoterpene alcohols, essential flavours, flavonoids and other poly-phenolic molecules. ${ }^{63-67}$

\section{Antimicrobial}

The antimicrobial action of cumin both oil and aqueous has assessed against a wide range of valuable and pathogenic gram-positive and gram-negative microbial strains. Cumin seed oil and alcoholic extract inhibited the growth of Klebsiella pneumoniae and its clinical isolates and caused improvement in cell morphology, capsule expression and decreased urease activity. Cumin has also found the biofilm-formation preventive properties against Streptococcus mutans and Streptococcus pyogenes. ${ }^{68-69}$ Cumin has shown the anti-fungal activity against food, soil, animal and human pathogens, yeasts, aflatoxins and mycotoxin producers. ${ }^{63,70-78}$

\section{Anticarcinogenic/antimutagenic}

The dietary supplements of cumin have prevented the occurrence of rat colon cancer induced by a colon-specific carcinogen and also decrease the activity of $\beta$-glucuronidase and mucinase enzymes. In cumin-colon treated rats, the levels of cholesterol, cholesterol/phospholipids ratio and 3-methylglutaryl COA reducates activity were reduced. ${ }^{79,80}$ The other inhibition activities of dietary cumin in mice are benzopyrene-induced for stomach tumorigenesis, 3-methylcholanthrene induced uterine cervix tumorigenesis, and 3-methyl-4-dimethyaminoazobenzene induced hepatomas.

\section{Antidiabetic}

Oral administration of cumin showed hypoglycemic effect in normal rabbit, resulting in significant decrease in the area under the glucose tolerance curve hyperglycemic peak. ${ }^{81}$ The biologically active constituent cuminaldehyde inhibited aldose reductase and alpha glucosidase II 'isolated from rat. ${ }^{82}$ In hyperlipidemia, when administered cumin by orally to alloxan induced iabetic rats, reduced the body weight, plasma and tissue cholesterol, phospholipids, free fatty acids and triglycerides and also decreased aspartate transaminase (AST), alkaline phosphatase (ALP) and $\gamma$-glutamyl transferase (GGT) activities and decreased the tissue (liver and kidney) levels of cholesterol, triglycerides and phospholipids.

\section{Immunomodulatory}

The oral treatment of cumin stimulated the T cells (CD4 and CD8) Th1 cytokines' expression in normal and cyclosporine-An induced immune suppressed animal. Cumin also depleted T lymphocytes, decreased the 
Table 3: Interaction and Side effect of Cumin

\begin{tabular}{|c|c|c|c|}
\hline Sr no & $\begin{array}{c}\text { Plant or Active } \\
\text { constituents }\end{array}$ & Interactive Drug/Herb & $\begin{array}{l}\text { Alter the } \\
\text { effects }\end{array}$ \\
\hline 1 & Cumin & 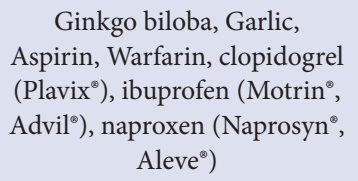 & $\begin{array}{c}\text { Increase the risk } \\
\text { of bleeding }\end{array}$ \\
\hline 2 & Cumin & $\begin{array}{l}\text { Antibiotics, anticancer drugs, } \\
\text { antifungals, anti-inflammatory } \\
\text { agents, antiseizure agents, } \\
\text { cholesterol lowering and lipid } \\
\text { lowering agents, drugs used } \\
\text { for osteoporosis, estrogens, } \\
\text { gastrointestinal agents, } \\
\text { morphine, opioids, and } \\
\text { phytoestrogens }\end{array}$ & $\begin{array}{l}\text { Affect the } \\
\text { immune system }\end{array}$ \\
\hline 3 & Cumin & $\begin{array}{c}\text { Glimepiride (Amaryl), } \\
\text { glyburide (DiaBeta, Glynase } \\
\text { PresTab, Micronase), } \\
\text { insulin, pioglitazone (Actos), } \\
\text { rosiglitazone (Avandia), } \\
\text { chlorpropamide (Diabinese), } \\
\text { glipizide (Glucotrol), } \\
\text { tolbutamide (Orinase) }\end{array}$ & $\begin{array}{c}\text { Decrease the } \\
\text { blood sugar } \\
\text { level }\end{array}$ \\
\hline 4 & Cumin & Anti-tuberculosis drugs & $\begin{array}{c}\text { Enhanced } \\
\text { rifampin levels }\end{array}$ \\
\hline 5 & Cumin & Cytochrome P450 & $\begin{array}{l}\text { Increase the } \\
\text { blood sugar } \\
\text { level }\end{array}$ \\
\hline
\end{tabular}

elevated corticosterone levels and size of adrenal glands and increased the weight of thymus and spleen in stress induced immune suppressed mice. $^{83}$

\section{Central nervous system}

The administration of cumin oil decreased the frequency of spontaneous activity induced by maximal electroshock and pentylenetetrazol (PTZ) in mice in time and concentration dependent and increased duration manner. ${ }^{84}$ Cuminaldehyde has tyrosinase inhibitor property that prevented the oxidation of 1-3.5- dihydroxyphenyklalanine (l-DOPA). ${ }^{85}$

\section{Estrogenic/anti-osteoporotic}

The presence of phytoestrogens in cumin has shown the anti-osteoporotic effect of reduced the urinary calcium excretion, augmentation of calcium content and mechanical strength of bones. ${ }^{86}$

\section{Other biodynamic actions}

Cumin has shown antitussive and produced relaxant effect by stimulating beta-adreno receptors and/or histamine $\mathrm{H} 1$ receptors. It has also shown antiaggregatory activity and inhibition of eicosanoid synthesis by inhibited arachidonic acid (AA)-induced platelet aggregation, thromboxane B2 production from exogenous AA and simultaneous increase in the formation of lipoxygenase. ${ }^{1,87}$

\section{Bioavailability enhancer}

The bioenhancer flavonoid glycoside 3', 5-dihydroxyflavone 7-O- $\beta$-dgalacturonide- $4^{\prime}$-O- $\beta$-d-glucopyranoside of cumin has shown a significant enhancement of rifampicin levels in rat plasma through the enhancement of peak concentration $\left(\mathrm{C}_{\max }\right)$ and area under the curve (AUC) of rifampicin by 35 and 53\%, respectively, when co-dosed with this molecule. ${ }^{88,89}$

\section{SIDE EFFECTS AND WARNING}

Cumin is a traditional and herbal plant that has various useful and curable effects but it also has some side effects. Side effects of cumin include contact dermatitis (skin rash from contact with an allergen or irritant), respiratory reactions, and liver cancer (above dietary levels), and lower blood sugar levels and also increase the risk of bleeding. ${ }^{58}$

A patient who suffers from ulcer and liver problems and also in women who are pregnant or breast feeding, they should have to use cumin with caution. Patients should also have to use cumin with caution who taking agents that affect the immune system, antibiotics, anticancer drugs, anti-fungal, anti-inflammatory agents, antioxidants, anti-seizure agents, cholesterol lowering and lipid lowering agents, estrogens, gastrointestinal agents, insecticides, iron, morphine, opioids, osteoporosis agents, painkillers, and phyto-estrogens. Cumin may alter the following effects, when used with specific drugs (Table 3).

\section{CONCLUSION}

Cuminum cyminum L., commonly known as cumin is a traditional, herbaceous plant and very popular spice since ancient times. Appearance and properties of apiaceae family member anise, fennel, caraway and black cumin were described similar to cumin fruits. Cumin was an icon for love and fidelity from middle ages. Cumin used as a flavoring agent to flavor the food and beverage and for pungency taste. According to the nutritional profile, cumin had a carbohydrate, protein, fat and soluble dietary fibers along with vitamins such as thiamine, riboflavin and niacin. It was also a rich source of iron and minerals, having $\mathrm{Fe}^{2+}(6.0)$ and $\mathrm{Zn}^{2+}(6.5)(\mathrm{mg} / 100 \mathrm{~g})$ that is useful to generate energy, immune systems and for skin disorders. Cumin has shown a lot of effects either as general use or pharmacological effects. Some side effects of cumin are also indicating the caution with therapeutic drugs but still it is a popular and nutrient contained spice in recent times.

\section{REFERENCES}

1. Srivastava KC. Extracts from Two Frequently Consumed Spices- Cumin (Cuminurn cyminum) and Turmeric (Curcuma longa) - inhibit platelet aggregation and alter eicosanoid biosynthesis in human blood platelets. Prostaglandins Leukotnenes and Essential Fatty Acids 1989; 137: 57-64.

2. Rebey IB, Jabri-Karoui I, Hamrouni-Sellami I, Bourgou S, Limam F, Marzouk B. Effect of drought on the biochemical composition and antioxidant activities of cumin (Cuminum cyminum L.) seeds. Industrial Crops and Products 2012; 36 238-245.

3. Jirovetz L, Buchbauer G, Stoyanova AS, Georgiev EV, Damianova ST. Composition, quality control and antimicrobial activity of the essential oil of cumin (Cuminum cyminum L.) seeds from Bulgaria that had been stored for up to 36 years. International Journal of Food Science and Technology 2005; 40: 305-310.

4. Hanif C, Ayesha T, Adila S, Saeed M, Tanveer A, Ashfaq M. Physico-chemical investigation and antimicrobial activity of essential oil of Cuminum cyminum L. World applied Sciences Journal. 2012; 19(3): 330-333

5. De M, De AK, Mukhopadhvay R, Banerjee AB, Micro M. Antimicrobial activity of Cuminum cyminum L. Ars Pharmaceutica 2003; 44: 257-69.

6. Derakhshan S, Sattari M, Bigdeli M. Effect of subinhibitory concentrations of cumin (Cuminum cyminum L.) seed essential oil and alcoholic extract on the morphology, capsule expression and urease activity of Klebsiella pneumoniae. Int J Antimicrob Agents 2008; 32: 432-436.

7. Khan IA, Abourashed EA. Leung's encyclopedia of common natural ingredients used in food, drugs and cosmetics. 3rd ed. John Wiley \& Sons Inc: Hoboken (New Jersey): 2011.

8. Kunzemann J, Herrmann K. Isolation and identification of flavon (ol)-o-glycosides in caraway (Carum carvi L.), fennel (Foeniculum vulgare Mill.), anise (Pimpinella anisum L.), and coriander (Coriandrum sativum L.), and of flavon-Cglycosides in anise. I. Phenolics of spices (author's transl). Z Lebensm Unters Forsch 1977; 164(3):194-200.

9. Matsumura T, Ishikawa T, Kitajima J. New p-menthanetriols and their glucosides from the fruit of caraway. Tetrahedron 2001; 57(38):8067-74.

10. Matsumura T, Ishikawa T, Kitajima J. Water-soluble constituents of caraway: 
aromatic compound, aromatic compound glucoside and glucides. Phytochemistry 2002; 61(4): 455-9.

11. Matsumura T, Ishikawa T, Kitajima J. Water-soluble constituents of caraway: carvone derivatives and their glucosides. Chem Pharm Bull 2002; 50(1): 66-72.

12. Najda A, Dyduch J, Brzozowski N. Flavonoid content and antioxidant activity of caraway roots (Carum carvi L.). Veg Crop Res Bull 2008; 68(1): 127-33.

13. Al-Bataina BA, Maslat AO, Al-Kofahi MM. Element analysis and biological studies on ten oriental spices using XRF and Ames test. J Trace Elem Med Biol 2003; 17(2): 85-90.

14. Raal A, Arak E, Orav A. The content and composition of the essential oil found in Carum carvi L. commercial fruits obtained from different countries. J Essent Oil Res 2012; 24(1): 53-9.

15. Razzaghi-Abyaneh M, Shams-Ghahfarokhi M, Rezaee MB, Jaimand K, Alinezhad S, Saberi R. Chemical composition and anti-aflatoxigenic activity of Carum carvi L., Thymus vulgaris and Citrus aurantifolia essential oils. Food Control 2009; 20(11): 1018-24.

16. Simic A, Rancic A, Sokovic MD, Ristic M, Grujic-Jovanovic S, Vukojevic J. Essential oil composition of Cymbopogon winterianus and Carum carvi and their antimicrobial activities. Pharm Biol 2008; 46(6): 437-41.

17. Jensen-Jarolim E, Leitner A, Hirschwehr R, Kraet D, Wuthrich B, Scheiner O, et al. Characterization of allergens in Apiaceae spices: anise, fennel, coriander and cumin. Clinical and Experimental Allerf>y 1997; 27: 299-1.106

18. Khader M, Bresgen N, Eckl PM. In vitro toxicological properties of thymoquinone. Food Chem Toxicol 2009; 47(1): 129-133.

19. El-Fatatry HM. Isolation and structure assignment of an antimicrobial principle from the volatile oil of Nigella sativa L. seeds. Pharmazie 1975; 30(2): 109-111.

20. Gali-Muhtasib H, Roessner A, Schneider-Stock R. Thymoquinone: a promising anti-cancer drug from natural sources. Int J Biochem Cell Biol 2006; 38: 1249-1253.

21. Salem ML. Immunomodulatory and therapeutic properties of the Nigella sativa L. seed. Int Immunopharmacol 2005; 5(13-14): 1749-1770.

22. Ali BH, Blunden G. Pharmacological and toxicological properties of Nigella sativa. Phytother Res 2003; 17(4): 299-305.

23. Burits M, Bucar F. Antioxidant activity of Nigella sativa essential oil. Phytother Res 2000; 14(5): 323-328

24. Hajhashemi V, Ghannadi A, Jafarabadi H. Black cumin seed essential oil, as a potent analgesic and anti-inflammatory drug. Phytother Res 2004; 18(3): 195-199.

25. Worthen DR, Ghosheh OA, Crooks PA. The in vitro anti-tumor activity of some crude and purified components of black seed, Nigella sativa L. Anticancer Res 1998; 18: 1527-1532.

26. Hosseinzadeh H, Parvardeh S, AsI MN, Sadeghnia HR, Ziaee T. Effect of thymoquinone and Nigella sativa seeds oil on lipid peroxidation level during global cerebral ischemia-reperfusion injury in rat hippocampus. Phytomedicine 2007; 14: 621-627.

27. Enomoto S, Asano R, IwahoriY, Narui T, OkadaY, Singab AN, et al. Hematological studies on black cumin oil from the seeds of Nigella sativa L. Biol Pharm Bull 2007; 28: 307-310

28. Chakravarty N. Inhibition of histamine release from mast cells by nigellone. Ann Allerg 1993; 70: 237-242.

29. Houghton PJ, Zarka R, De Las Heras B, Hoult RS. Fixed oil of Nigella sativa and derived thymoquinone inhibit eicosanoid generation in leukocytes and membrane lipid peroxidation. Planta Med 1995; 61: 33-36.

30. Mansour MA, Nagi MN, El-Khatib AS, Al-Bekairi AM. Effects of thymoquinone on antioxidant enzyme activities, lipid peroxidation and DT-diaphorase in different tissues of mice: A possible mechanism of action Cell. Biochem Funct 2002; 20: 143-151.

31. Mansour MA. Protective effects of thymoquinone and desferrioxamine against hepatotoxicity of carbon tetrachloride in mice. Life Sci 2000; 66: 2583-2591.

32. Boulos L. Medicinal Plants of North Africa. $1^{\text {st }}$ Edn. Reference Pubns: Algonac: Ml; 1983. ISBN: 10: 0917256166. p. 286.

33. Agarwal R, Kharya MD, Shrivastava R. Antimicrobial and anthelminthic activities of the essential oil of Nigella sativa Linn. Indian J Exp Biol 1979; 17: 1264-1265.

34. Akhtar MS, Riffat S. Field trial of Saussurea lappa roots against nematodes and Nigella sativa seeds against cestodes in children. J Pak Med Assoc 1991; 41: 185-187.

35. Mahmoud MR, El-Abhar HS, Saleh S. The effect of Nigella sativa oil against the liver damage induced by Schistosoma mansoni infection in mice. J Ethnopharmacol 2002; 79: 1-11.

36. Aboul-Ela MA, El-Shaer NS, Ghanem NB. Antimicrobial evaluation and chromatographic analysis of some essential and fixed oils. Pharmazie 1996; 51: 993-994.

37. Hanafy MS, Hatem ME. Studies on the antimicrobial activity of Nigella sativa seed (black cumin). J Ethnopharmacol 1991; 34: 275-278.

38. Aboul-Ela El. Cytogenetic studies on Nigella sativa seeds extract and thymoquinone on mouse cells infected with schistosomiasis using karyotyping. Mutat Res Genet Technol Enviorn 2002; 516: 11-17.

39. Salem ML, Hossain MS. Protective effect of black seed oil from Nigella sativa against murine cytomegalovirus infection. Int J Immunopharmacol 2000; 22 729-740.
40. Chand S, Sahrawat AK, Prakash DV S S R. In vitro Culture of Pimpinella anisum L. (anise). J Plant Biochemistry \& Biotechnology 1997; 6: 91-95.

41. Singh G, Maurya S, DeLampasona MP, Catalan C. Chemical constituents, antimicrobial investigations and antioxidative potential of volatile oil and acetone extract of star anise fruits, Sci Food Agric 2006; 86:111-121.

42. Farooq A, Muhammad A, Hussaina Al, Muhammad S. Antioxidant and antimicrobial activities of essential oil and extracts of fennel (Foeniculum vulgare Mill.) seeds from Pakistan, Flavour Fragr J 2009; 24: 170-176.

43. Thippeswamy NB, Naidu KA. Antioxidant potency of cumin varieties cumin black cumin and bitter cumin-on antioxidant systems. Eur Food Res Technol 2005; 220: 472-476.

44. Hajlaoui H, Mighri H, Noumi E, Snoussi M, Trabelsi N, Ksouri R, et al. Chemical composition and biological activities of Tunisian Cuminum cyminum L. essentia oil: a high effectiveness against Vibrio spp. strains. Food Chem Toxicol 2010; 48 2186-2192.

45. Daniel Z, Maria H. Domestication of Plants in the Old World, $3^{\text {rd }}$ ed. Oxford: University Press; 2000. vol. 531. p. 206

46. Allahghadri T, Rasooli I, Owlia P, Nadooshan MJ, Ghazanfari T, Taghizadeh M, et al. Antimicrobial property, antioxidant capacity, and cytotoxicity of essential oil from cumin produced in Iran. J Food Sci 2010;75(2):H54-H61.

47. lacobellis NS, Cantore PL, Capasso F, Senatore F. Antibacterial activity of Cuminum cyminum L. and Carum carvi L. essential oils. J Agric Food Chem 2005; 53: 57-61.

48. El-Kani M, Fereshteh G, Mehdi M, Soosan R. Extraction of volatile oil from cumin (Cuminum cyminum L.) with superheated water. Journal of food process engineering 2007; 30(2): 255-266.

49. Li R, Jiang ZT. Chemical composition of the essential oil of Cuminum cyminum L. from China. Flav Fragr J 2004; 19: 311-313.

50. Gallo M, Ferracane R, Giulia G, Ritieni A, Fagliano V. Microwave assisted extrac tion of phenolic compounds from four different spices. Molecules 2010; 15(3): 6366-6374.

51. Fadel H, Marx F, El-Sawy A, El-Ghorab A. Effect of extraction techniques on the chemical composition and antioxidant activity of Eucalyptus camaldulensis var. brevirostris leaf oils. Zeitschrift für Lebensmitteluntersuchung und-Forschung $A$ 1999; 208: 212-6.

52. Morshedi D, Aliakbari F, Tayaranian M, Fassihi P. Cuminaldehyde as the major component of cuminum cyminum, a natural aldehyde with inhibitory effect on alpha synuclein fibrillation and cytotoxicity. Journal of Food Science 2015: 80(10): H2336- $\mathrm{H} 2345$

53. Goto T, Takahashi N, Hirai S, Kawada T. Various terpenoids derived from herbal and dietary plants function as PPAR modulators and regulate carbohydrate and lipid metabolism. PPAR research 2010;1-9.

54. Sekine T, Sugano M, Majid A, Fujii Y. Antifungal effects of volatile compounds from black zira (Bunium persicum) and other spices and herbs. Journal of chemical ecology 2007; 33: 2123-32.

55. Lee HS. Cuminaldehyde: aldose reductase and $\alpha$ - glucosidase inhibitor derived from Cuminum cyminum L. seeds. Journal of agricultural and food chemistry 2005; 53: 2446-50.

56. Morshedi D, Aliakbari F. The inhibitory effects of cuminaldehyde on amyloid fibrillation and cytotoxicity of alpha-synuclein. Modares Journal of Medical Sciences: Pathobiology 2012; 15: 45-60.

57. Bennett MA, Huang TN, Matheson TW, Smith AK, Nickerson W. ( 76 - Hexamethylbenzene) ruthenium complexes. Inorganic Syntheses 1982; 21: 74-78.

58. Johri RK. Cuminum cyminum and Carum carvi: An update. Pharmacogn Rev 2011; 5(9): 63-72.

59. Al-Hashemi FHY. Chromatographic separation and identification of some volatile oils, organic acids and phenols from the seeds of cuminum cyminum growing in Iraq. IJRRAS 2014; 19(1): 80 -90.

60. Lahlou S, Tahraoui A, Israili Z, Lyoussi B. Diuretic activity of the aqueous extracts of Carum carvi and Tanacetum vulgare in normal rats. J Ethnopharmacol 2007: 110: 458-63.

61. Tahraoui A, El- Hilay J, Israili ZH, Lyoussi B. Ethnopharmacological survey of plants used in the traditional treatment of hypertension and diabetes in southeastern Morocco (Errachidia province). J Ethnopharmacol 2007; 110: 105-17.

62. Leporatti ML, Ghedira K. Comparative analysis of medicinal plants used in traditional medicine in Italy and Tunisia. J Ethnobiol Ethnomed 2009; 5: 31-9.

63. De ML, De FV, Fratianni F, Nazzaro F. Chemistry, antioxidant, antibacterial and antifungal activities of volatile oils and their components. Nat Prod Commu 2009; 4: 1741-50.

64. Najda A, Dyduch J, Brzozowski N. Flavonoid content and antioxidant activity of caraway roots (Carum carvi L.). Veg Crops Res Bull 2008; 68:127-33.

65. Samojlik I, Lakic N, Mimica-Dukic N, Dakovic-Svajcer K, Bozin B. Antioxidant and hepatoprotective potential of essential oils of coriander (Coriandrum sativum L.) and caraway (Carum carvi L.) (Apiaceae). J Agric Food Chem 2010; 58: 8848-53.

66. Ruberto G, Baratta MT. Antioxidant activity of selected essential oil components in two lipid model systems. Food Chem 2000; 69: 167-74.

67. Rodov V, VinokurY, Gogia N, Chkhikvishvili I. Hydrophilic and lipophilic antioxidant capacities of Georgian spices for meat and their possible health implications. 
Georgian Med News 2010;179: 61-6.

68. Derakhshan S, Sattari M, Bigdeli M. Effect of cumin (Cuminum cyminum L) seed essential oil on biofilm formation and plasmid integrity by Klebsiella pneumoniae. Pharmacog Mag 2010; 6: 57-61.

69. Shayegh S, Rasooli I, Taghizadeh M, Astaneh SD. Phytotherapeutic inhibition of supragingival dental plaque. Nat Prod Res 2008; 22:428- 39.

70. Hajlaoui H, Mighri H, Noumi E, Snoussi M, Trabelsi N, Ksouri R. Chemical composition and biological activities of Tunisian Cuminum cyminum L. essential oil: A high effectiveness against Vibrio spp. strains. Food Chem Toxicol 2010 48: 2186-92.

71. Mehdi RA, Masoomch SG, Mohammad BR, Kamkar J, Soheil A, Reza S. Chemical composition and antiaflatoxicogenic activity of Carum carvi L., Thymus vulgaris and Citrus aurantifolia essential oils. Food Contr 2009; 20: 1018-24.

72. Boyraz N, Ozcan, M. Antifungal effect of some spice hydrosols. Fitoterapia 2005; 76: 661-5.

73. Farag RS, Daw ZY, Abo-Raya SH. Influence of some spice essential oils on Aspergillus parasiticus growth and production of aflatoxins in a synthetic medium. J Food Sci 1989; 54:74-6.

74. Farag RS, Daw ZY, Hewedi FM, El Baroty GS. Antimicrobial activity of some Egyptian spice essential oils. J Food Prot 1989; 52: 665-7.

75. Hammad AAI, Youssef BM. Growth inhibition of some pharmacological molds by garlic and cumin essential oils. Egypt J Microbiol 1995; 29: 115-20.

76. Razzaghi-Abyaneh M, Shams-Ghahfarokhi M, Rezaee MB, Jimand K, Alinezahad S, Saberi R. Chemical composition and antiaflatoxigenic activity of Carum carvi L, Thymus vulgaris and Citrus aurantifolia essential oils. Food Contr 2009; 20: 1018-24

77. Romagnoli C, Andreotti E, Maietti S, Mahendra R, Mares D. Antifungal activity of essential oil from fruits of Indian Cuminum cyminum. Pharm Biol 2010; 48: 834-48.

78. Skrinjar MM, Mandi Al, Misan AC, Sakac MB, Saric LC, Zec MM. Effect of mint (Mentha piperita L.) and Caraway (Carum carvi L.) on the growth of some toxicogenic Aspergillus species and aflatoxin B1 production. Proc Nat Sci Matica Srpska Novi Sad 2009; 116:131-9.

79. Nalini N, Sabitha K, Vishwanathan P, Menon VP. Influence of spices on the bacterial (enzyme) activity in experimental colon cancer. J Ethnopharmacol 1998; 62: 15-24.

80. Nalini N, Manju V, Menon VP. Effect of spices on lipid metabolism in 1, 2-dimethylhydrazine-induced rat colon carcinogenesis. J Med Food 2006; 9: 237-45

81. Roman-Ramos R, Flores-Saenz JL, Alarcon-Aguilar FJ. Antihyperglycemic effect of some edible plants. J Ethnopharmacol 1995; 48: 25-32.

82. Lee HS. Cuminaldehyde: Aldose Reductase and alpha glucosidase inhibitor derived from Cuminum cyminum L. seeds. J Agric Food Chem 2005; 53: 2446-53.

83. Chauhan PS, Satti NK, Suri KA, Amina M, Bani S. Stimulatory effects of Cuminum cyminum and flavonoid glycoside on cyclosporine-A and restraint stress induced immune-suppression in swiss albino mice. Chem Biol Interac 2010; 185: 66-72.

84. Sayyah M, Mahboubi A, Kamalinejad M. Anti-convulsant effect of the fruit essential oil of Cuminum cyminum in mice. Pharmaceut Biol 2002; 40: 478-80.

85. Kubo I, Kinst-Hori I. Tyrosinase inhibitors from cumin. J Agric Food Chem 1998; 46: $5338-41$

86. Malini T, Vanithakumari G. Estrogenic activity of Cuminum cyminum in rats. Indian J Exp Biol 1987; 25: 442-4.

87. Srivastava KC, Mustafa T. Pharmacological effect of spices: Eicosanoid modulating activities and their significance in human health. Biomed Rev 1994; 2 : 15-29.

88. Sachin BS, Monica P, Sharma SC, Satti NK, Tikoo MK, Tikoo AK. Pharmacokinetic interaction of some antitubercular drugs with caraway: Implications in the enhancement of drug bioavailability. Hum Exp Toxicol 2009; 28: 175-84.

89. Sachin BS, Sharma SC, Sethi S, Tasduq SA, Tikoo MK, Tikoo AK. Herbal modulation of drug bioavailability: Enhancement of rifampicin levels in plasma by herbal products and a flavonoid glycoside derived from Cuminum cyminum. Phytother Res 2007; 21:157-63.

\section{GRAPHICAL ABSTRACT}

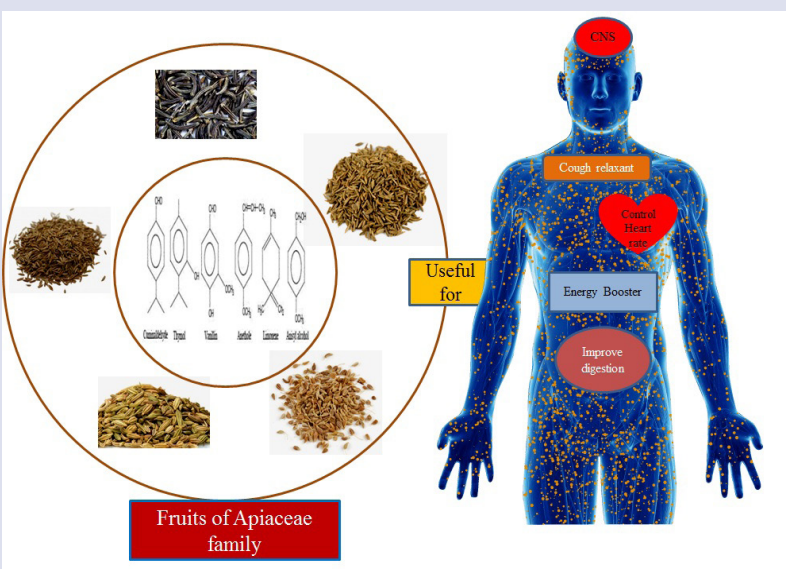

\section{SUMMARY}

- Cumin (Cuminum cyminum) is one such most popular spice that is used as a culinary spice for their special aromatic effect. Cumin is available in different appearances such as anise, fennel, caraway and black cumin and the difference between them is their characteristics. In cumin, contains an important component such as pinene, cymene, terpinene, cuminaldehyde, oleoresin, thymol and others that have shown their uses according to the disease. Cumin has proved several benefits with the help of availability of nutrients. It is an important element of iron for energy, immunity systems, lactation and skin diseases. Cumin also shown various pharmacological effects but has some side effects.

\section{AUTHORS}

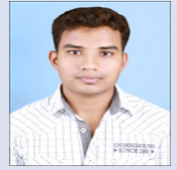

Mr. Rudra Pratap Singh: completed B. Pharm in the year of 2012 from CSVTU, Bhilai (C.G.) and M. Pharm in the year of 2014 from Pune University, Pune. Currently He is working as a Ph.D research scholar in the Dept. of Pharmaceutics, JSS College of Pharmacy, Mysuru. He is interested in Novel Drug delivery systems and Nanotechnology.

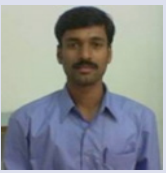

Dr. H.V. Gangadharappa, Ph.D: Completed M. Pharm, in Pharmaceutics in the year of 2005 from Rajiv Gandhi University of Health Science, Bangalore and PhD 2013 from JSS College of Pharmacy, Mysuru. Presently He is working as an Assistant Professor in the Dept. of Pharmaceutics at JSS College of Pharmacy, Mysuru, which is a constituent college of JSS University, Mysuru, India. He has 8 years of teaching and research experience. His area of research is floating drug delivery systems and nanosponges 
Dr. K. Mruthyunjaya, Ph.D: Completed M. Pharm, in Pharmacognosy in the year 1999 from Govt. College of Pharmacy, Bangalore and PhD 2009 from Rajiv Gandhi University of Health Sciences, Karnataka, Bengaluru. Presently Dr. Mruthunjaya is working as a Professor in the Dept. of Pharmacognosy at JSS College of Pharmacy, Mysuru, which is a constituent college of JSS University, Mysuru, India. He has long 17 years of teaching and research experience in the said college. His area of research is identify-ing, screening and validation of antioxidant herbs for their various biological properties.

Cite this article: Singh RP, Gangadharappa HV, Mruthunjaya K. Cuminum cyminum - A Popular Spice: An Updated Review. Pharmacogn J. 2017;9(3):292-301. 